\title{
La terra del Vello d'oro tra mito e realtà storica: Vani through Virtual Heritage, il rilievo per la valorizzazione dell'archeologia della Colchide
}

\author{
Paola Puma
}

\section{Abstract}

II mito del Vello d'oro costituisce lo sfondo della narrazione che sin dall'antichità lega circolarmente Occidente e Oriente nella vicenda degli Argonauti ma ha la sua collocazione storica a Vani, capitale dell'antica Colchide situata nell'attuale Georgia caucasica.

II progetto italo-georgiano Vani through Virtual heritage, configurato per costruire una prima documentazione di un importante patrimonio archeologico mai finora descritto con approccio multidisciplinare e finalizzato alla successiva ricostruzione unitaria del contesto, è imperniato sul rilievo e sulla rappresentazione intesi come strumento di conoscenza e valorizzazione del multiscalare contesto archeologico che abbraccia varie dimensioni, da quella ambientale e architettonica a quella del reperto mobile. I più significativi esiti provvisoriamente disponibili consistono in restituzioni e visualizzazioni. Fanno capo al primo tipo i rilievi di 4 strutture architettoniche della Upper Terrace e della cosiddetta 'città bassa' di Vani e di circa 20 reperti mobili di varia grandezza rilevati presso il Vani Archaeological Museum ed il Georgian National Museum, descritti tramite grafici in scala 1:20- 1:50 per le strutture e in scala 1:2 per i reperti mobili. Rientrano nel secondo gruppo i due layout concepiti per costituire il futuro supporto divulgativo di questo importante patrimonio della Colchide: il dispositivo di musealizzazione articolato in forma multimediale ed interattiva - video e responsive 3D - e in forma fisica, tramite una postazione low cost per la proiezione degli ologrammi di due gioielli d'oro provenienti dai corredi funebri di una nobildonna e del guerriero Dédato.

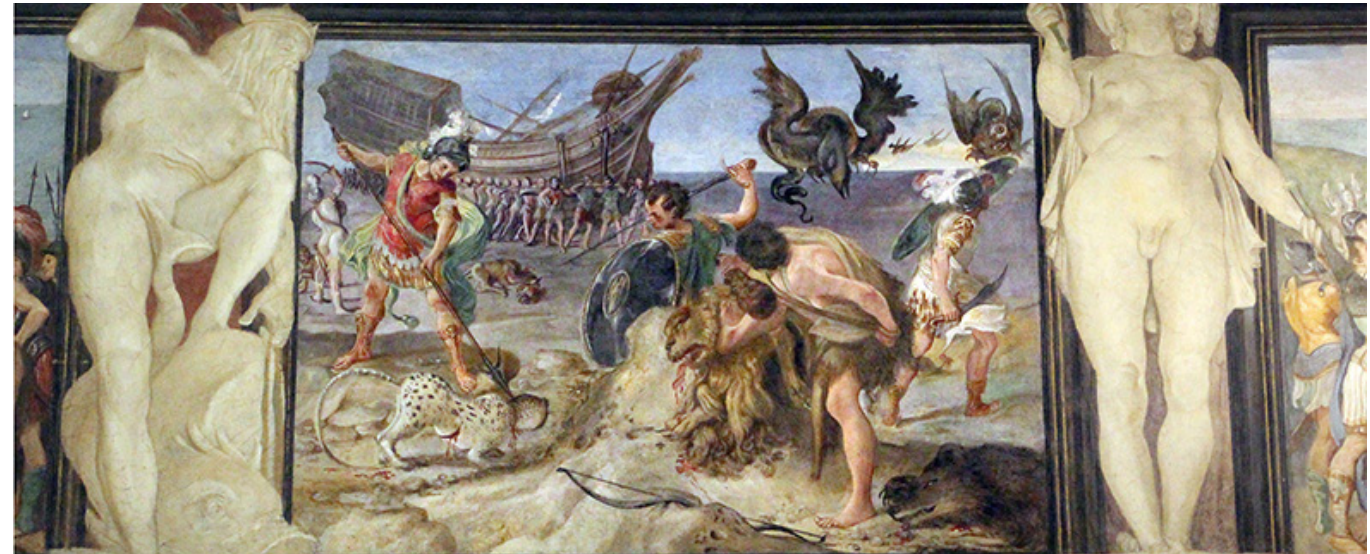


Tra Europa ed Asia, la Georgia: il mito, la storia, i luoghi

II complesso mito del Vello d'oro costituisce lo sfondo di tre diverse vicende in una narrazione unitaria che si svolge tra Oriente e Occidente attraversando circolarmente l'Europa, l'Asia Minore, il Mediterraneo (fig. I).

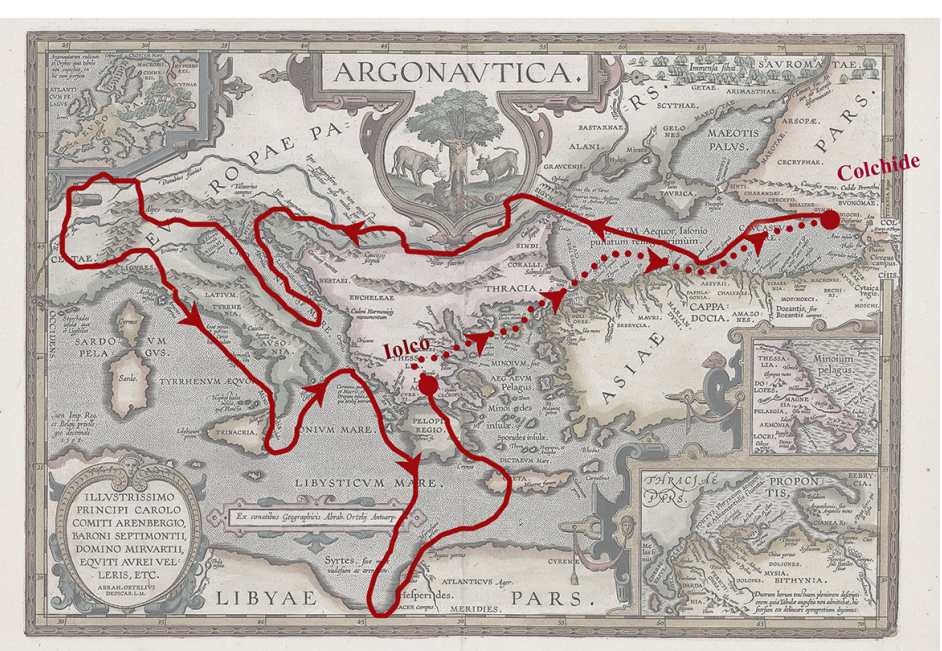

L'origine del mito è principalmente legata alle Argonautiche, poema odeporico di Apollonio Rodio risalente al III sec. a.C., ma la vicenda del recupero del manto del montone alato Crisomallo, ritenuto dotato di proprietà magiche e curative [I], da parte del gruppo costituito da Giasone, da Medea e dagli Argonauti esprime poi la sua potenza narrativa in molte opere che nei secoli hanno interessato la produzione artistica di ogni tipo [2] [D'Acchille 20 I I, pp. 2I-27] (fig. 2).

Fig. 2. II mito del vello d'oro nell'arte:

1) Gustave Moreau, Jason e Medea, 1865, Parigi,

Museo d'Orsay;

2) Bertel Thorvaldsen,

Jason, I802-1803, Co-

penhagen, Thorvaldsens Museum;

3) Pietro Francavilla,

Giasone, I589- 1590

Firenze, Museo Nazionale del Bargello;

4) Annibale, Agostino e

Ludovico Carracci, Storie di Giasone e Medea (particolare), I 854, Bologna, Palazzo Fava:

5) Don Chaffey, Jason

and the Argonauts, 1963;

6) Riccardo Freda, I

giganti della Tessaglia (Gli

Argonauti), 1960.
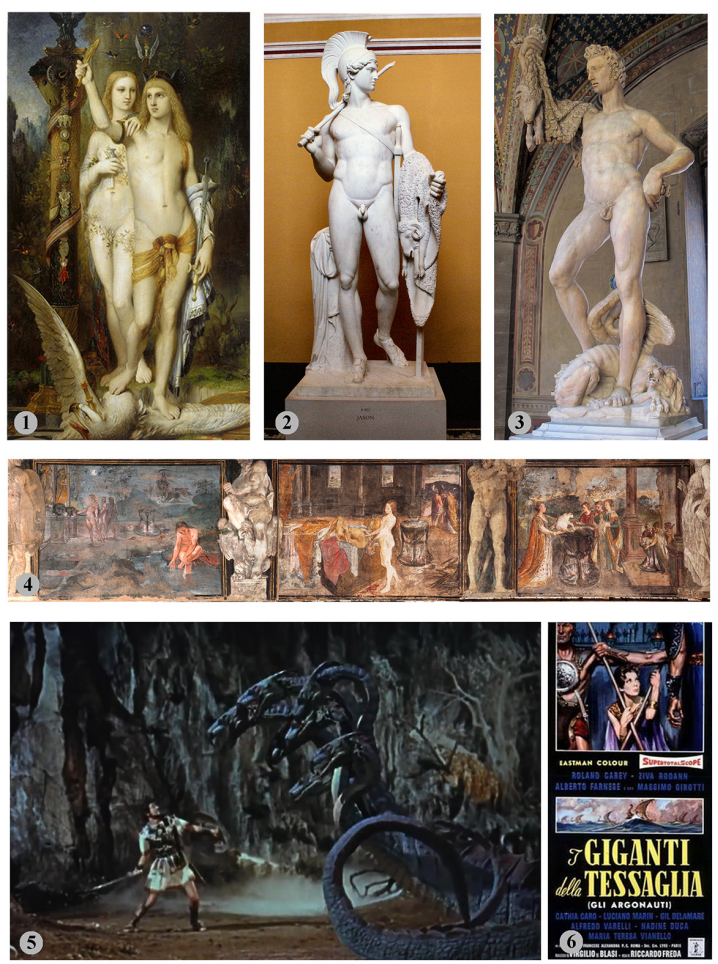
Ad un immaginario mitico così forte si sovrappone la vicenda storica che vede la Colchide - regione affacciata sul mar Nero e parte occidentale della Georgia caucasica dove si è da sempre cercato di individuare un limite certo e confine geografico tra Europa e Asia (fig. 3) - perdere ripetutamente la sua originaria unità a seguito di una serie di invasioni: prima da parte di Sciti e Cimmeri nella seconda metà del VII sec. a.C., poi teatro di aspre guerre nel sec.VI fra i Bizantini e i Persiani, che cercarono ripetutamente di aprirsi attraverso la regione uno sbocco sul Mar Nero, e finite con l'annessione di Dario I alla XIX satrapia dell'Impero Persiano (5 I 5-5 I 0 a.C.).

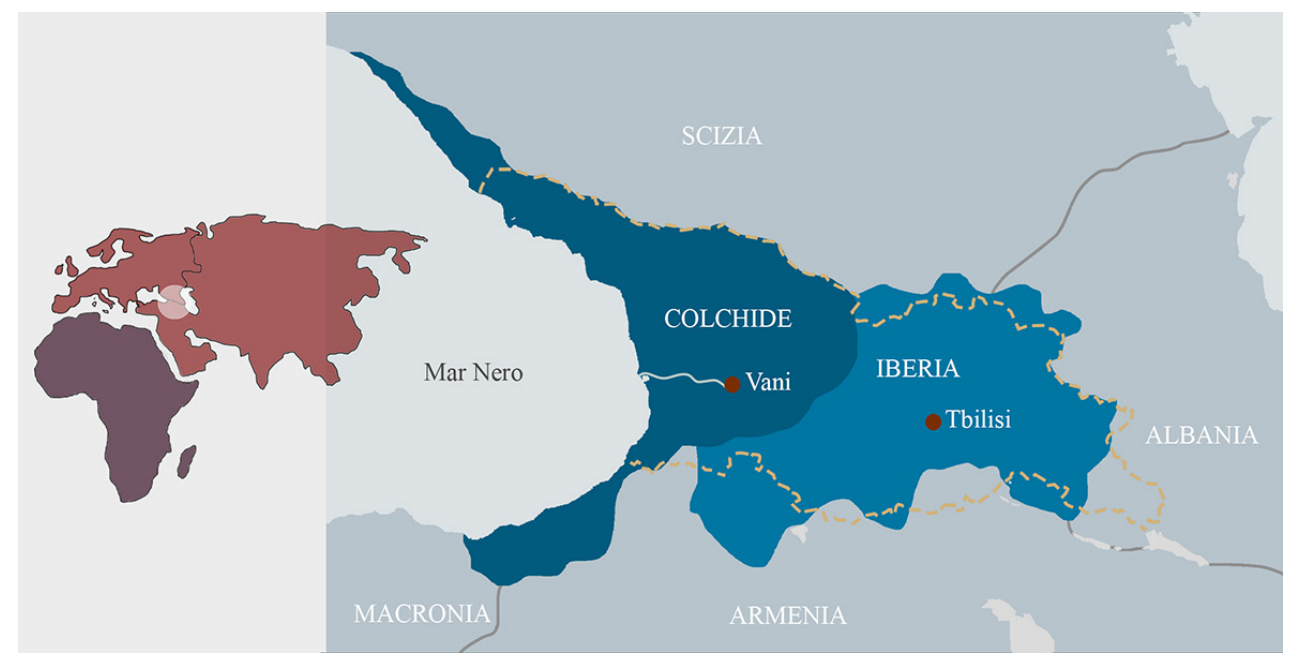

Nell'orbita della Persia sino alla conquista di Alessandro, fece più tardi parte della monarchia pontica, alla cui dissoluzione fu incorporata alla provincia di Ponto e Bitinia. La regione finì infine sotto il dominio romano durante la terza guerra mitridatica di Gneo Pompeo Magno (65 a.C.).

La vicenda della importante e ricca città di Vani si colloca nell'arco dei 5 secoli che vanno dal VIII secolo a.C. alla distruzione nel 47 a.C.

La prima fase della città è datata tra I'VIII e il VII secolo a.C., periodo nel quale Vani era già rilevante centro di culto. Nel VI secolo a.C. i greci iniziano a fondare sulle coste del Mar Nero alcune città commerciali, portando Vani al centro delle principali rotte commerciali che attraversavano la Transcaucasia per giungere all'approdo del porto di Phasis, l'odierna Poti posta a circa $70 \mathrm{~km}$ da Vani (fig. 4).

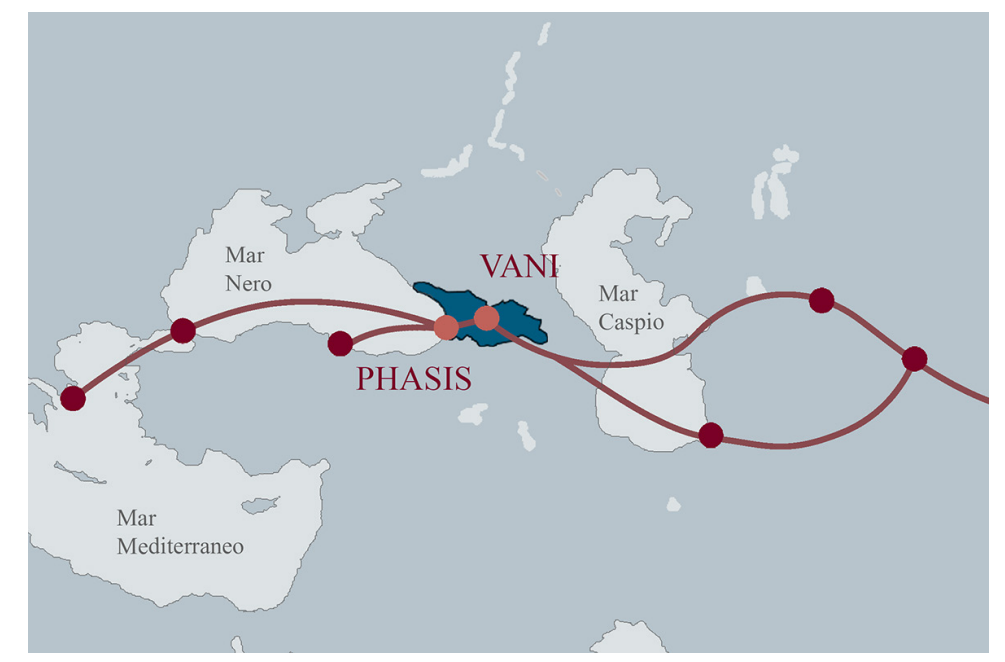


In questa fase che durerà fino al III secolo a. C.Vani subisce l'influenza della cultura greca, e i luoghi di sepoltura già insediati a partire dall'VIII secolo si arricchiscono di oggetti in oro, argento e bronzo finemente lavorati mentre intorno alla città santuario vengono erette fortificazioni lignee a segnalare l'importanza della città come centro politico e amministrativo del regno [Kacharava, Faudot, Geny 2005].

A partire dal 350 a.C. circa e fino al I secolo a. C.Vani diventa un'importante città-tempio del mondo ellenistico; in questa fase vengono edificati il Round Temple, una serie di altari sacrificali e fortificazioni in muratura (fig. 5).

L'assetto definitivo delle mura si situa intorno al 250 a.C., fase alla quale vengono riferiti i due altari tuttora visibili e nuovi edifici adornati da sculture in bronzo.

Nel 65 a. C. tutta la Colchide perde definitivamente di centralità e autonomia eVani stessa vede spegnersi la sua importanza: una prima distruzione attribuita al re del Ponto Farnace II avviene nel 49 a.C. mentre nel 47 a.C. la città viene distrutta definitivamente da Mitridate di Pergamo [Treccani online, lemmi: Apollonio Rodio, Argonauti, Colchide].

Fig. 5. La città-tempio di Vani ellenistica tra il 350 a.C. e il I secolo a.C: : il Round Temple (nella Città bassa), una serie di altari sacrificali e le fortificazioni che circondavano linsediamento.

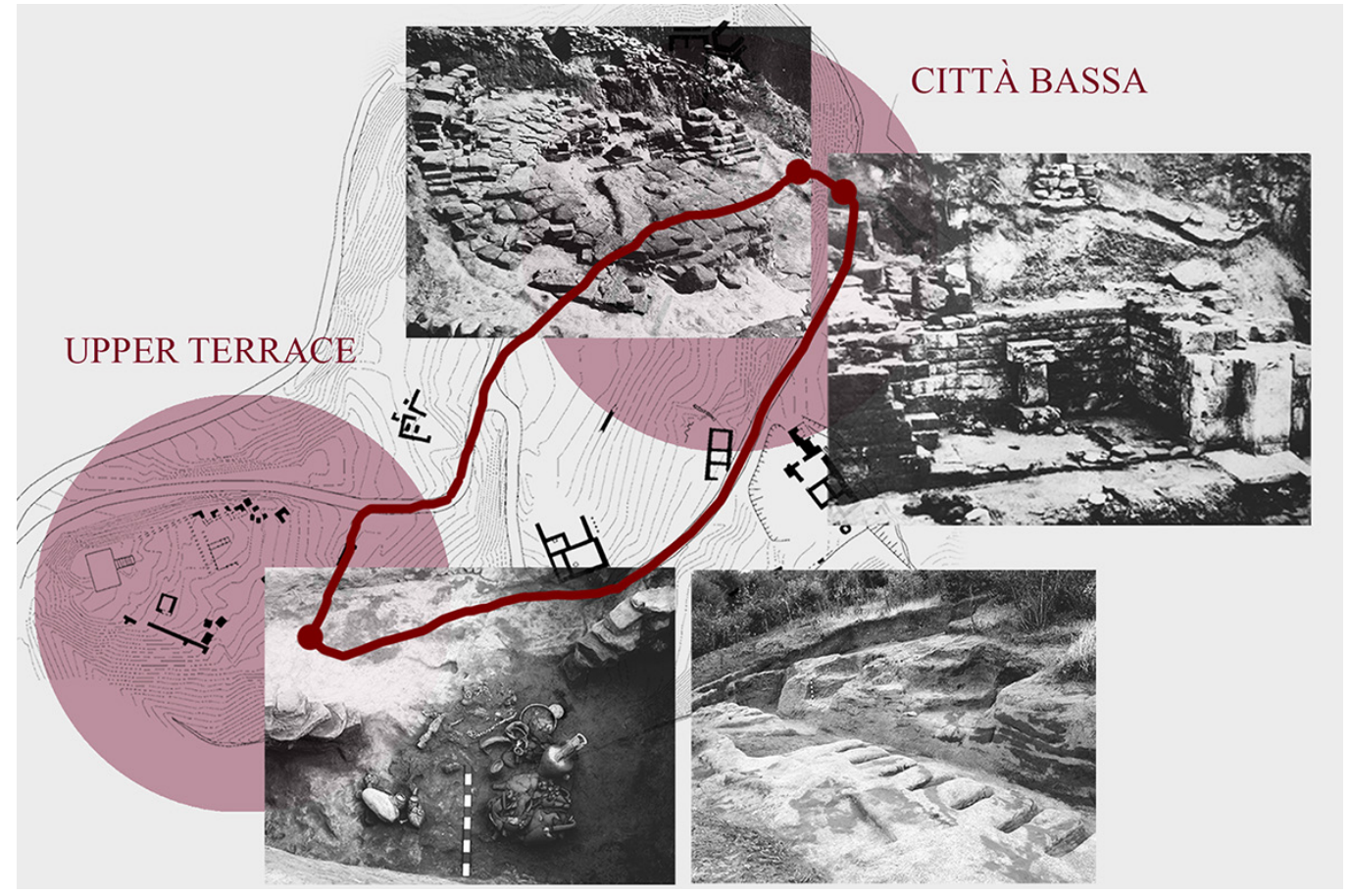

II progetto Vani through Virtual heritage: documentazione e rilievi per la valorizzazione del patrimonio archeologico

Le ricerche dello storico ed archeologo Takaishvili, che a cavallo tra XIX e XX secolo iniziò a studiare la storia dell'insediamento, precedono le prime sistematiche campagne archeologiche condotte nell'area di Vani solo a partire dal 1947.

L'antica Vani sorgeva su una collina alta circa I 40 metri sulla vallata sottostante, pianura solcata dal fiume Sulori affluente del Rioni, l'antico Fasi alla cui foce Giasone e compagni nascosero l'Argo in un'ombrosa palude, gettarono l'ancora e si riunirono per discutere la strategia da adottare per impossessarsi del vello d'oro.

II sito, attualmente studiato solo per circa un terzo della sua estensione, ha prodotto una mole di manufatti sorprendente per numero e tipologia: dalla fase VIII-VI secolo a.C. pochi e gravemente danneggiate ceramiche colchis e animali di argilla; dalla seconda fase (inizio $\mathrm{VI}$ - metà IV secolo a.C.) ceramiche dipinte di importazione greca e nuovi tipi di manufatti 
per il cibo. Ma la più rilevante restituzione di pezzi funerari provenienti dai ricchi siti di sepoltura è rappresentata da gioielli d'oro, ornamenti d'argento e di bronzo ritrovati in gran numero insieme a graziose sculture in bronzo e lussuosi oggetti indicativi dell'appartenenza dei defunti all'élite al potere.

La pur qualificata letteratura di documentazione archeologica presenta uno stato dell'arte datato e frammentario nel tempo; ciò non consente accesso a dati aggiornati nè accoppiamenti certi tra reperto e contesto di provenienza [Lordkipanidze 1991; Gamkrelidze 20I2].

Nel 2017 viene pertanto messo a punto e avviato il progetto italo-georgiano Vani Virtual heritage [3], configurato per costruire una prima documentazione dell'importante patrimonio archeologico di Vani e consentire una prima ricostruzione unitaria del contesto, oggi impossibile per la frammentarietà delle fonti e la dispersione di collocazione dei resti mobili; il progetto è imperniato sul rilievo e sulla rappresentazione intesi come strumento di conoscenza del contesto archeologico nell'accezione di ambiente complesso costituito da un habitat multi scalare che abbraccia la dimensione ambientale e architettonica fino al reperto mobile [Puma, Nicastro 2018].

Il programma di lavoro è stato messo a punto grazie alla formazione di un team interdisciplinare di architetti e archeologi, si svolge coniugando didattica e ricerca ed è finalizzato alla restituzione metrica, morfologica e tematica del continuum ambientale di contesto tramite output digitali grafici statici e dinamici basati su ricostruzioni scientificamente validati (Principles of Seville, 20II).

\section{Metodologia di lavoro}

Il workflow di progetto integra procedure tradizionali tese ad acquisire e restituire coppie di set informativi relativi ai reperti ed alla relativa struttura architettonica di provenienza (Bertocci, Arrighetti 2015; Brusaporci 2015); la sinossi procedurale (fig. 6) comprende le seguenti fasi di lavoro, svolte in un lasso di tempo di circa 6 mesi:

A - FASE I - rilievo digitale:

I) documentazione preliminare: consistente nella ricerca sul caso di studio selezionando ed elaborando bibliografia, elaborati grafici, iconografia e documentazione fotografica esistenti;

2) progetto di rilievo: il sopralluogo sul sito e la visita al Georgian National Museum di Tbilisi sono stati i primi step delle attività svolte in Georgia per acquisire conoscenza diretta del patrimonio archeologico di studio in confronto con i dati acquisiti dalle fonti e definire il progetto di rilievo indicando il dettaglio delle operazioni da compiere, il cronoprogramma delle attività e la suddivisione dei compiti per la realizzazione del rilievo;

3) acquisizione da rilievo diretto e sfm delle permanenze architettoniche: effettuato tramite misurazioni del registro metrico di supporto al fotogrammetrico speditivo;

4) acquisizione da rilievo sfm dei reperti archeologici: effettuato tramite campagna fotografica, con controllo metrico e del colore, dei reperti nel Vani Archaeological Museum e nel Georgian National Museum;

5) archiviazione e catalogazione dei dati raccolti: effettuato tramite organizzazione dei dati raccolti secondo una gerarchia articolata in 4 livelli;

6) post processing e elaborazione: il post processing è stato effettuato tramite estrazione ed elaborazione dei dati attraverso due idonei software di fotomodellazione differenziati in funzione della scala dei resti, se struttura o reperto;

7) restituzioni grafiche statiche e dinamiche: la restituzione grafica $2 D$ è stata eseguita tramite restituzioni fotorealistiche, al tratto e materiche in scala differenziata per le strutture e per i reperti (in scala 1:20, I:50, I: I 00 per le strutture e in scala 1:2 per i reperti mobili); affiancano i disegni, i modelli 3D generati dalla fotomodellazione che saranno successivamente elaborati anche in visualizzazioni dinamiche;

B - FASE II - progetto di comunicazione visiva e musealizzazione digitale: la finalizzazione provvisoria del progetto è costituita dalla produzione di due tipi di supporto visivo rap- 
presentati da un video descrittivo dellintero piano di lavoro e dagli ologrammi di reperti mobili;

C - FASE III - progetto di musealizzazione fisica: la previsione di finalizzazione finale del progetto riguarda una ipotesi di musealizzazione del sito, almeno nelle sue componenti di minimale attrezzatura dei servizi informativi e didattici.

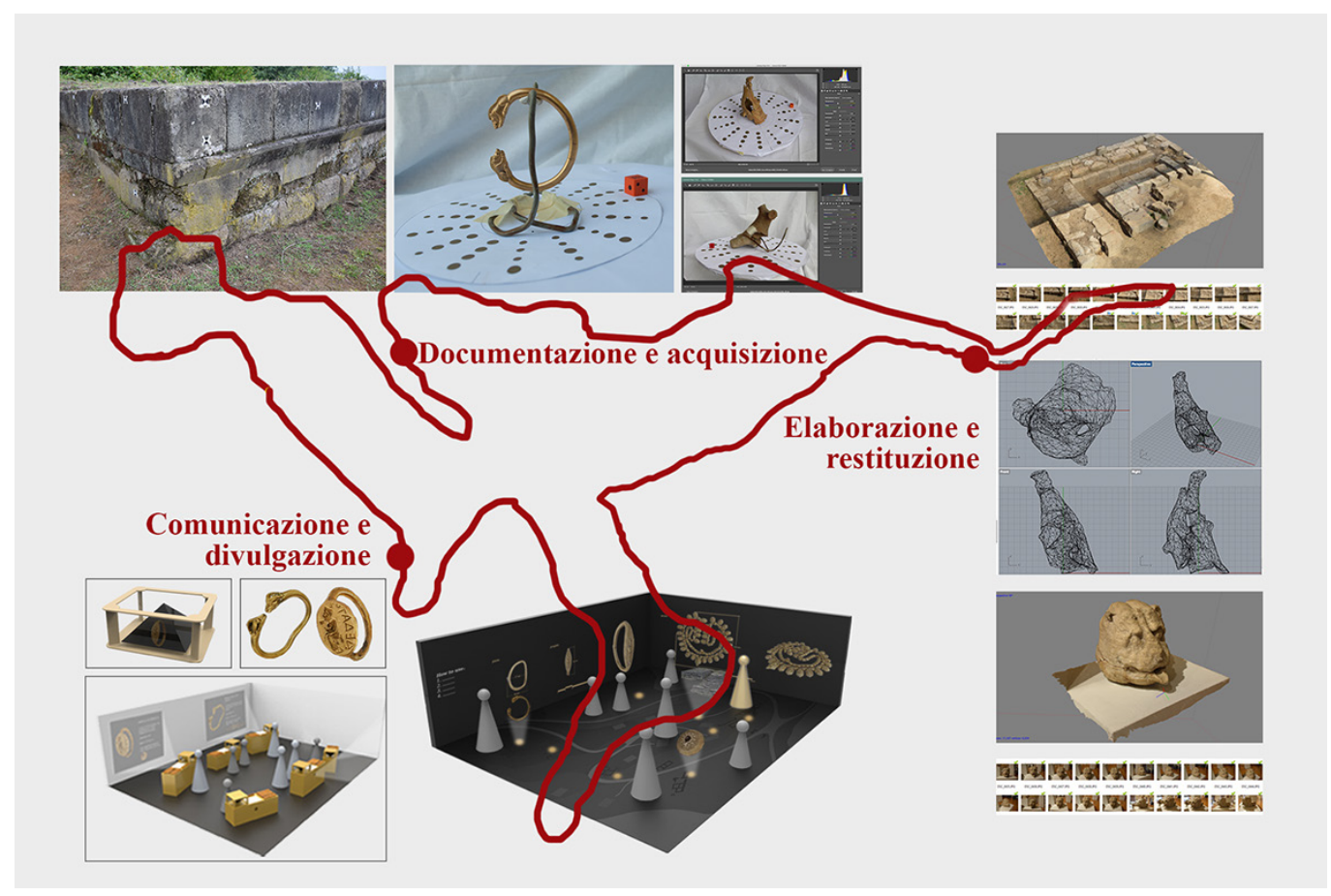

\section{Risultati e primi esiti}

Come accennato sopra, per indisponibilità della documentazione oppure per obliterazione della struttura, non sempre è stato possibile ricollegare i reperti esposti all'edificio di provenienza, perciò anche strutture e materiali mobili non ricollegabili sono stati ugualmente rilevati a solo scopo documentario.

Nella Upper Terrace, sono stati rilevati le strutture senza reperti ricollegabili di un altare cerimoniale, il "santuario I" e 17 reperti provenienti da contesti oggi non più visibili: dalla cosiddetta Tomba della nobile, un bracciale con arieti, un bracciale con cinghiali, un anello con incisione; dalla Tomba del guerriero Dédato: I'anello ed una patera; dalla Tomba 4, un bracciale da bambino, in oro con terminali a testa di ariete, (III sec. a.C.); dall'UpperTerrace e datate al VIII-VII sec. a.C., due figurine di quadrupedi ed una di ariete, tutte in terracotta; provenienti da un ambiente con altare non rilevabile situato nel complesso difensivo nella Città Bassa, un'anfora, frammenti di una pavimentazione in ciottolato, un vaso; infine, 4 suppellettili ceramiche ed una statuetta bronzea di figura femminile (fig. 7).

In funzione stretta della finalità del progetto, teso a ricostruire in virtual heritage i contesti unitariamente descritti tramite la ricollocazione dei reperti nell'edificio di provenienza, dalla complessiva campagna di rilievo sono state successivamente selezionate 2 strutture e, presso il Vani Archaeological Museum, 3 reperti ad esse collegabili, costituiti da materiali mobili di varia natura (suppellettili e frammenti architettonici).

In particolare, sono stati oggetto di studio con restituzione tematizzata le strutture con reperti ricollegabili: nella Città Bassa il complesso difensivo (insieme a un calice zoomorfo) e l'altare cerimoniale (con ad esso ricollegabili un frammento di bassorilievo ed una antefissa) (fig. 8). 
Oltre a questi reperti ricollocabili, destinati ad essere restituiti compiutamente in vari dispositivi di comunicazione del patrimonio, presso il Georgian National Museum, sono stati rilevati i più rilevanti ritrovamenti provenienti da Vani: l'importante torso in bronzo di un giovane, datato al II secolo a.C., un capitello in pietra localizzato nell'area del Round Temple, due teste leonine in pietra, facenti parte di un sistema di scolo dell'acqua provenienti dalla Città Bassa (fig. 9).

Pur essendo la civiltà della Colchide importantissima area archeologica, i reperti di maggior pregio provenienti da Vani e dalla sua regione sono stati spostati nel Georgian National Museum della capitale Tbilisi; il sito archeologico di Vani risulta perciò poco valorizzato e sconosciuto ai più sia per la collocazione geografica non centrale che per la mancanza di informazioni facilmente reperibili, e quindi tagliato fuori dalle principali rotte turistiche. In questo quadro si situa l'intento del secondo asse del progetto, finalizzato all'allestimento di questa documentazione scientifica anche in chiave divulgativa.

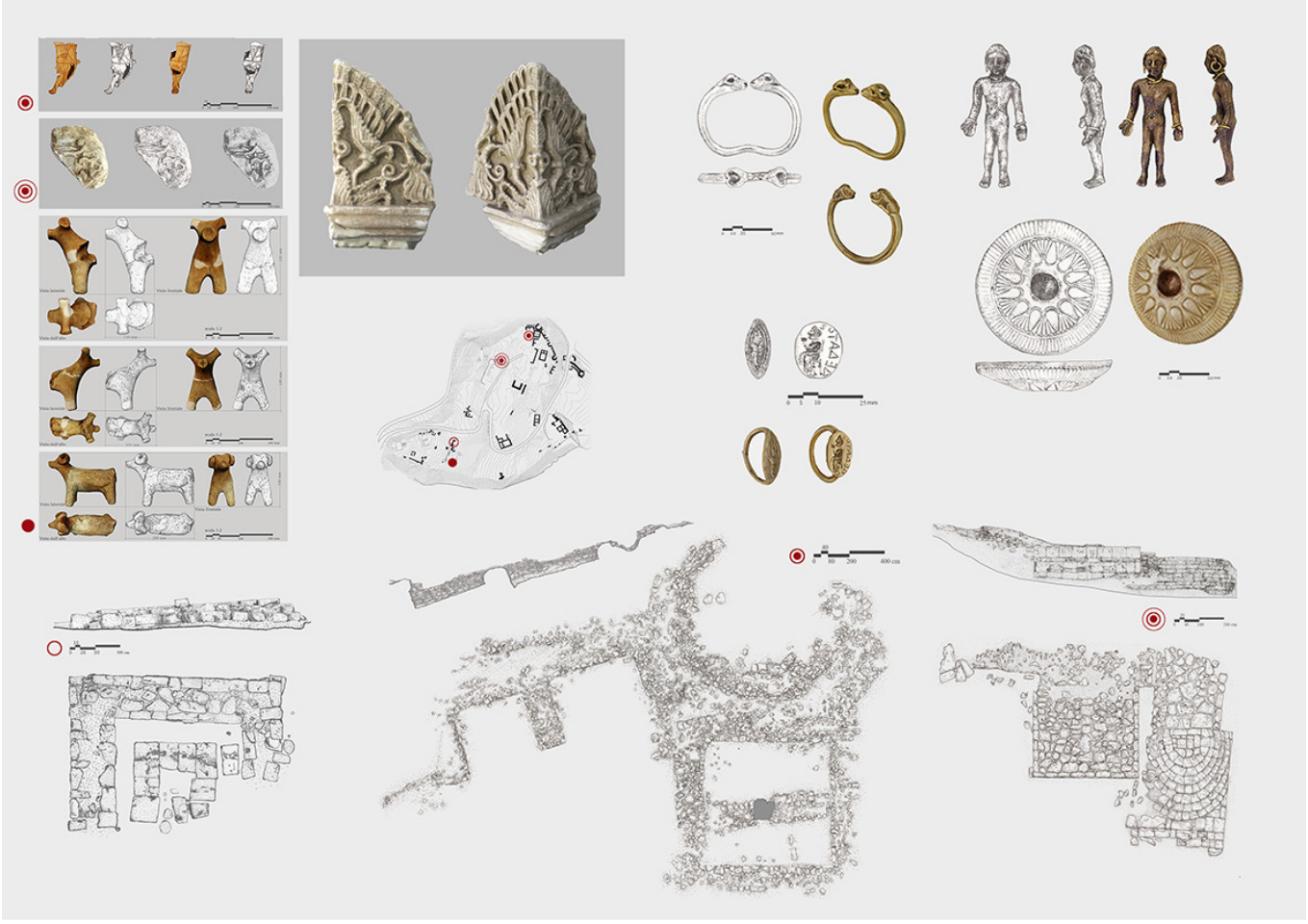

Fig. 8. Fasi di lavorazione di permanenze da Vani: altare cerimoniale (fine I secolo a. C.).
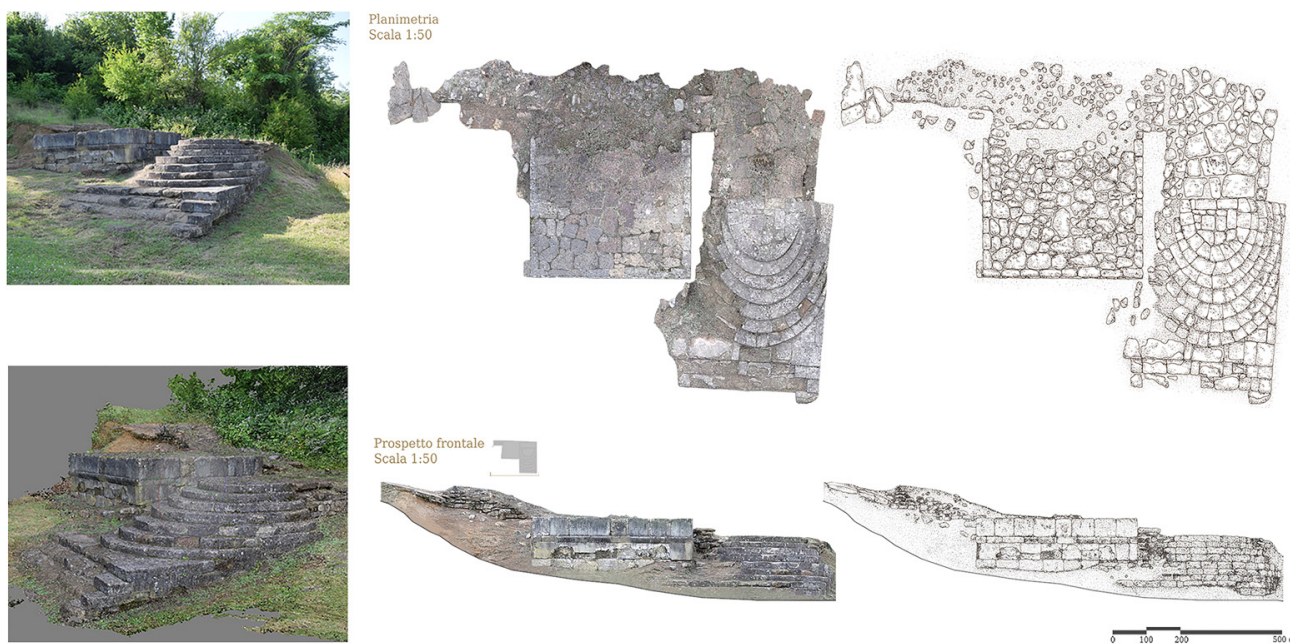
II sistema concepito per la presentazione della prima ricognizione documentaria sopra descritta è articolato su tre assi di azione: disseminazione dei risultati, musealizzazione dei reperti, musealizzazione del sito.

Ad ogni asse corrisponde poi una serie di esiti differenziati per output e scelta comunicativa. La disseminazione dei risultati consiste, infatti, di un primo step nel quale è stato realizzato un video impostato sia come base informativa di panoramica che come necessario riferimento per le successive future potenziali scelte comunicative.

Tra le molte modalità di rappresentazione e storytelling, il video è stato scelto per la semplicità di realizzazione, la potenzialità di una restituzione multiscalare, dalla visione d'insieme alla descrizione di elementi particolari e dettagli, per la versatilità di utilizzo da vari accessi mobile e on site, la flessibilità comunicativa adatta ad essere tarata in molte corde di edutainment. II video organizza e mostra gli attuali contenuti di documentazione del sito anche nella prospettiva di realizzare in secondo step un modello 3D di tipo responsive che fornisca un'informazione via via più complessa di ricostruzione unitaria del contesto e modularmente arricchita di contenuti.

La musealizzazione dei reperti è invece concepita in due scale di soluzione espositiva: off site e on site, entrambe basate su supporti per la visualizzazione degli ologrammi disponibili in vari formati e adatti a diverse tipologie di dispositivi mobili.

La musealizzazione del sito, infine, prevede una proposta progettuale basata sul superamento delle criticità attualmente presenti nel sito, soffermandosi sulle principali: l'assenza di percorsi strutturati di visita dei resti, limitazioni di accesso alle aree archeologiche, assenza di strutture informative e servizi, scarsa organizzazione della struttura museale.

Fig. 9. Fasi di lavorazione di resti da Vani: torso di un giovane (statua in bronzo, Il secolo a. C.) figure animali (statue e sime in pietra, II-I secolo a. C.).
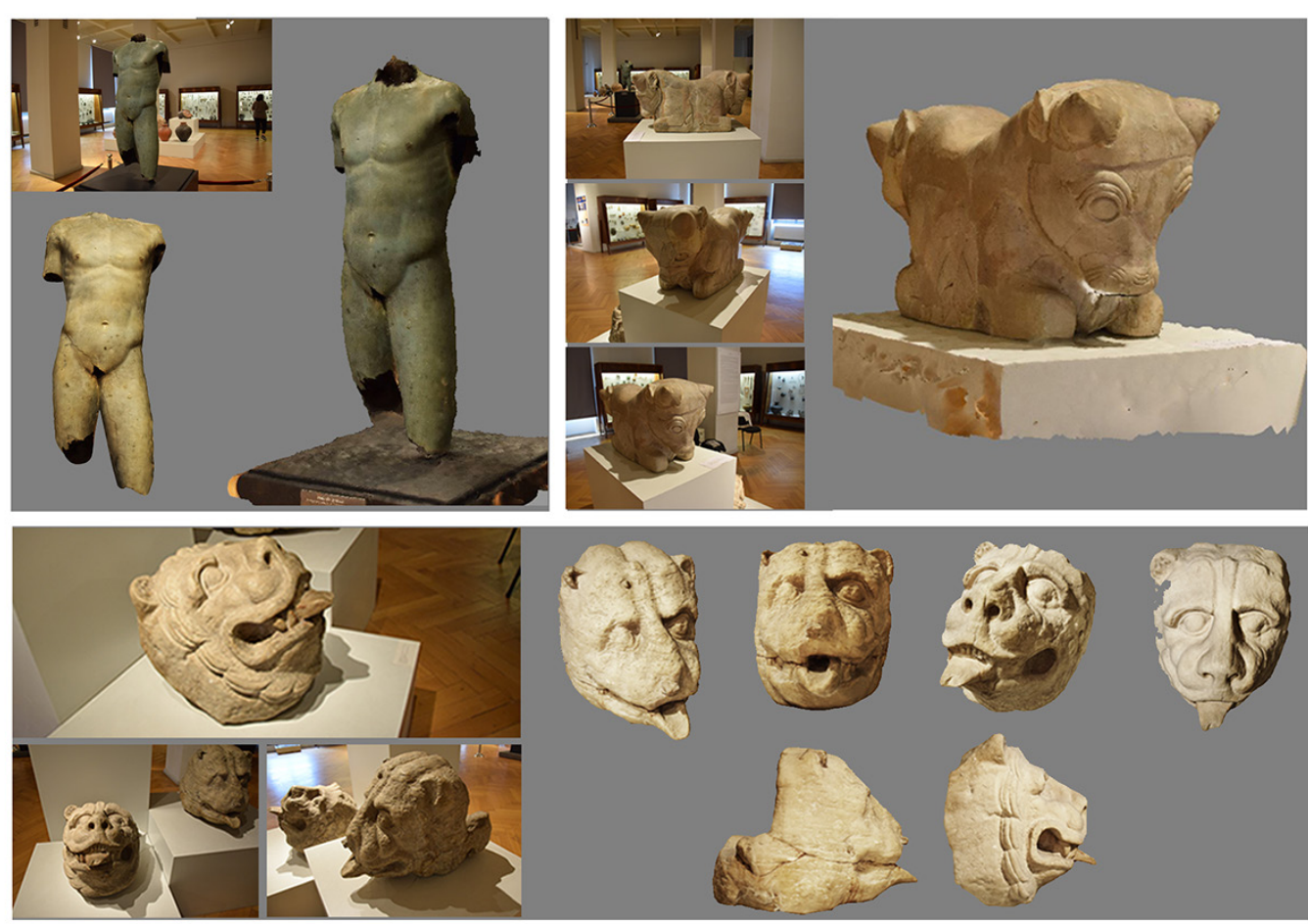

\section{Note}

[I] Nella regione che aveva a Vani una città nodale del regno colco, l'antico uso delle pelli dei montoni usate come setacci per la ricerca dell'oro nei fiumi e messe ad asciugare appese agli alberi per estrarne le particelle auree, non può non collegare questa usanza alla nascita del mito della Colchide come di una zona letteralmente risplendente d'oro al sole (www.treccani. it/colchide).

[2] La trasmissione del mito nel tempo si è espressa innanzitutto grazie alla lirica di Pindaro ed ai 4 libri del poema epico delle Argonautiche di Apollonio Rodio, ma poi successivamente in varie altre forme: da quella teatrale a quella figurativa su ceramica, scultura, pittura, ai media cinematografici e televisivi, fino alla più recente divulgazione ludica dei giochi da tavolo e dei videogiochi. 
[3] Vani through Virtual heritage è stato messo a punto per la missione svoltasi nel 2017 in Georgia nell'ambito dell'accordo di collaborazione culturale e scientifica tra I'Università degli Studi di Firenze e la Tbilisi State Academy of Art (responsabili dell'accordo, Paola Puma e Nana lashvili). Nell'ambito della missione è stato svolto il workshop congiunto per l'acquisizione dei dati del seminario The enhancement of the Georgian archaeological heritage: surveys and representation methodologies in cui congiuntamente a quella del docente è stata effettuata la mobilità di un Phd student dell'Ateneo di Firenze e di tre laureandi, con esiti sviluppati in tre tesi di laurea (Elena Leonardi Vugi, Vani, la Colchide oltre il mito del Vello d'Oro: il rilievo per la documentazione; Adele Rossi, Vani, la Colchide oltre il mito del Vello d'Oro: il rilievo per la musealizzazione dei reperti; Cristina Scicchitano, Vani, la Colchide oltre il mito delVello d'Oro: il rilievo per la musealizzazione del sito; relatore prof.ssa Paola Puma, correlatore arch. Giuseppe Nicastro, Cdl in Scienze dell' Architettura).

\section{Riferimenti bibliografici}

Akhvlediani Dimitri, Amaghlobeli Badri, Chi Jennifer, Chichinadze Maia, et al. (2016). The Hoard from the City-Site of Vani. In Bulletin of the Georgian National Academy of Sciences, vol. I0, n. 2, pp. I82-191.

Bertocci Stefano, Arrighetti Andrea (2015). Survey and documentation for archaeology. In SCIRES-it, 5 (2): <http://caspurciberpublishing.it/index.php/scires-it>.

Blázquez Martinez José María (2005). The sanctuary-city of Vani and its parallels in the west. In Kacharava Daredjan, Faudot Murielle et Geny Evelyne (eds.). Pont-Euxin et polis: polis hellenis et polis barbaron. Actes du Xe Symposium de Vani, 23-26 septembre 2002: Hommage à Otar Lordkipanidzé et Pierre Lévêque, pp. 235-244. Publications de l'Institut des Sciences et Techniques de l'Antiquité [PUFC 979], Besançon: Presses Universitaires de Franche-Comté.

Brusaporci Stefano (20 I5). Handbook of research on emerging digital tools for architectural surveying, modeling, and representation. Hershey: Igi Global, 2015.

D'Acchille Tiziana (20I I). Alle origini della cultura occidentale. In D'Acchille Tiziana. II Vello d'Oro, antichi tesori della Georgia. Roma: Palombi, pp. 2 1 - 27

Gamkrelidze Gela (20 I2). Researches in Iberia-colchology (History and archaeology of ancient Georgia).Tbilisi: Otar Lordkipanidze centre of archaeology of Georgian National Museum.

Kacharava Daredjan, Faudot Murielle, Geny Evelyne (2005). Pont-Euxin et polis: polis hellenis et polis barbaron. Actes du Xe Symposium de Vani, 23-26 septembre 2002: Hommage à Otar Lordkipanidzé et Pierre Lévêque. Publications de l'Institut des Sciences et Techniques de l'Antiquité [PUFC 979], Besançon: Presses Universitaires de Franche-Comté.

Kacharava Darejan, Kvirkvelia Guram (2009). Recent Archaeological Finds on the Upper Terrace of the Vani Site. In Ancient Civilizations from Scythia to Siberia, nr. 14.

Kacharava Darejan, Kvirkvelia Guram, Chi Jennifer (2008). Wine, Worship, and Sacrifice:The Golden Graves of Ancient Vani. Princeton: Princeton University Press.

Kipiani Guram (20|4). The city of Suriumi.Tbilisi: Artanuji.

Lordkipanidze Otar (199I).Vani: an ancient city of Colchis. Greek. In Roman and Byzantine Studies, 32:2, pp. I5I - 195.

Lordkipanidze Otar (1995). Vani une Pompéi géorgienne (Traduzione di Evelyne Geny). Paris: Les Belles Lettres.

Lordkipanidzé Otar (2002). Trade on the Black Sea. An historic forerunner of the Great Silk Road. In Murielle Faudot, Arlette Fraysse et Evelyne Geny (eds.). Pont Euxin et commerce: la genèse de la "route de la soie". Actes du IXe Symposium de Vani (Colchide, 1999). Publications de l'Institut des Sciences et Techniques de l'Antiquité [PUFC 979], Besançon: Presses Universitaires de Franche-Comté, pp. 7-13.

Pescarin Sofia (2016). Digital Heritage into Practice. In SCIRES-it, 6 (I): <http://www.sciresit.it/issue/view/772. Principles of Seville, International principle of Virtual Archaeology, 20l I. http://smartheritage.com/wp-content/uploads/20I5/03/FINALDRAFT.pdf>.

Puma Paola, Nicastro Giuseppe (2018). La documentazione del patrimonio Caucasico: esperienze interdisciplinari in Georgia ed Armenia/The documentation of the Caucasian heritage: interdisciplinary experiences in Georgia and Armenia. In Bertocci Stefano (ed.). Programmi multidisciplinari per l'internazionalizzazione della ricerca. Firenze: Didapress, pp. 22 I-225.

Remondino Fabio, Campana Stefano (2014). 3D Recording and Modeling in Archaeology and Cultural Heritage. Theory and best practices. BAR International Series 2598. Oxford: Archaeopress.

Spagnesi Piero (20 I I). Geografia architettonica dell'antica Colchide fino al primo secolo d.C.. In D'Acchille Tiziana. II Vello d'Oro, antichi tesori della Georgia. Roma: Palombi, pp. 35-57.

Treccani online, www.treccani.it/: lemmi: Argonauti, Colchide.

Autore

Paola Puma, Università di Firenze, paola.puma@unifi.it

Per citare questo capitolo: Puma Paola (2020). La terra del Vello d'oro tra mito e realtà storica: Vani through Virtual Heritage, il rilievo per la valorizzazione dell'archeologia della Colchide/The Land of the Golden Fleece between Myth and Historical Reality: Vani through Virtual Heritage, the Survey for the Enhancement of Colchis Archaeology. In Arena A., Arena M., Brandolino R.G., Colistra D., Ginex G., Mediati D., Nucifora S., Raffa P. (a cura di). Connettere. Un disegno per annodare e tessere. Atti del $42^{\circ}$ Convegno Internazionale dei Docenti delle Discipline della Rappresentazione/ Connecting. Drawing for weaving relationships. Proceedings of the 42th International Conference of Representation Disciplines Teachers. Milano: FrancoAngeli, pp. 2622-2639. 


\title{
The Land of the Golden Fleece between Myth and Historical Reality: Vani through Virtual Heritage, the Survey for the Enhancement of Colchis Archaeology
}

\author{
Paola Puma
}

\section{Abstract}

The myth of the Golden Fleece constitutes the background of the narrative that has linked the West and the East in the Argonauts story since ancient times but has its historical location in Vani, the capital of ancient Colchis located in actual Caucasian Georgia. The Italian-Georgian joint project Vani through Virtual heritage has been conceived to build a first documentation of an important archaeological heritage never described so far with a multidisciplinary approach and aimed at the subsequent unitary reconstruction of the context. The project is focused on the survey and representation intended as a tool of knowledge and enhancement of the multiscale archaeological context that embraces the environmental, the architectural and the finds scale.

The most significant outcomes of the project currently available consist of representations and visualizations. The first type includes the surveys of 4 architectural structures of the UpperTerrace and of the so-called "lower city" of Vani and of about 20 finds of various kinds in the Vani Archaeological Museum and the Georgian National Museum, described by graphs in scale 1:20 - 1:50 for the structures, and $1: 2$ for the finds. The second group includes the two outputs conceived to constitute the future dissemination support of the important heritage of Colchis: the multimedia and interactive museum system -the video and the responsive 3D- and the museum architecture, through as a low cost workstation for the projection of the holograms of two gold jewels from the grave of a noblewoman and the warrior Dédato.

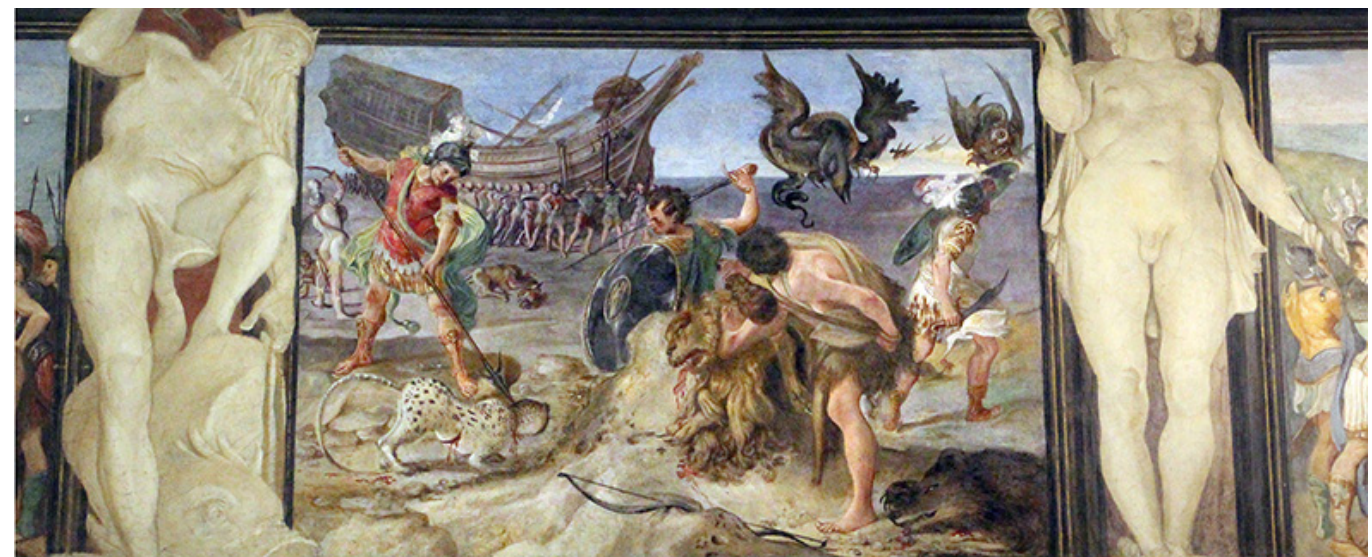




\section{Between Europe and Asia, Georgia: the myth, the history, the places}

The complex myth of the Golden Fleece constitutes the backdrop for three different events in a unitary narrative that takes place between East and West, circularly crossing Europe, Asia Minor, the Mediterranean (fig. I).

Fig. I. The journey of the Argonauts through Europe, Asia Minor and the Mediterranean.
Fig. 2. The myth of the golden fleece in art: i) Gustave Moreau, Jason e Medea, 1865, Paris, d'Orsay Museum; 2) Bertel Thorvaldsen Jason, I 802-1803, Copenhagen, Thorvaldsens Museum;

3) Pietro Francavilla, Giasone, 1589-1590, rence Museo Nazionale del Bargello:

4) Anniba, Arostino 4) Annibale, Agostino e Ludovico Carracci, Storie of Jason and Medea (detail), 1854, Bologna, Palazzo Fava;

5) Don Chaffey, Jason and the Argonauts, 1963; 6) Riccardo Freda,The giants of Tessaly (The Argonauts), 1960

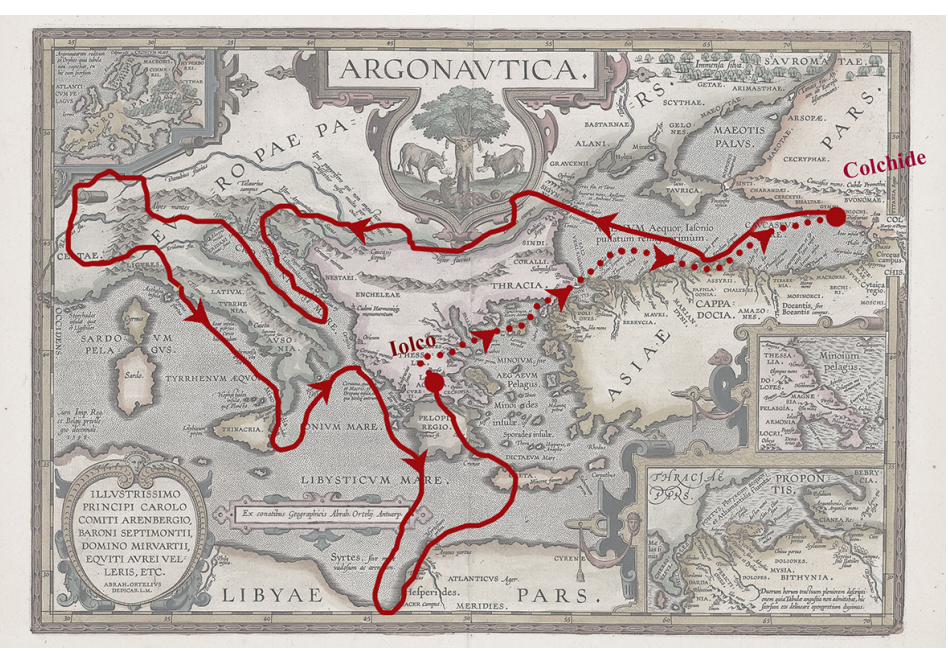

The origin of the myth is mainly linked to the Argonautics, an odeporic poem by Apollonius Rodio dating back to the third century BC, but the story of the recovery of the coat of the winged mutton Crisomallo, believed to have magical and healing properties [I], by the group of Jason, Medea and the Argonauts then expresses its narrative power in many artworks that over the centuries have been created as the artistic production of many kinds [2] [D'Acchille, 20 I I, pp. 2I-27] (fig. 2).
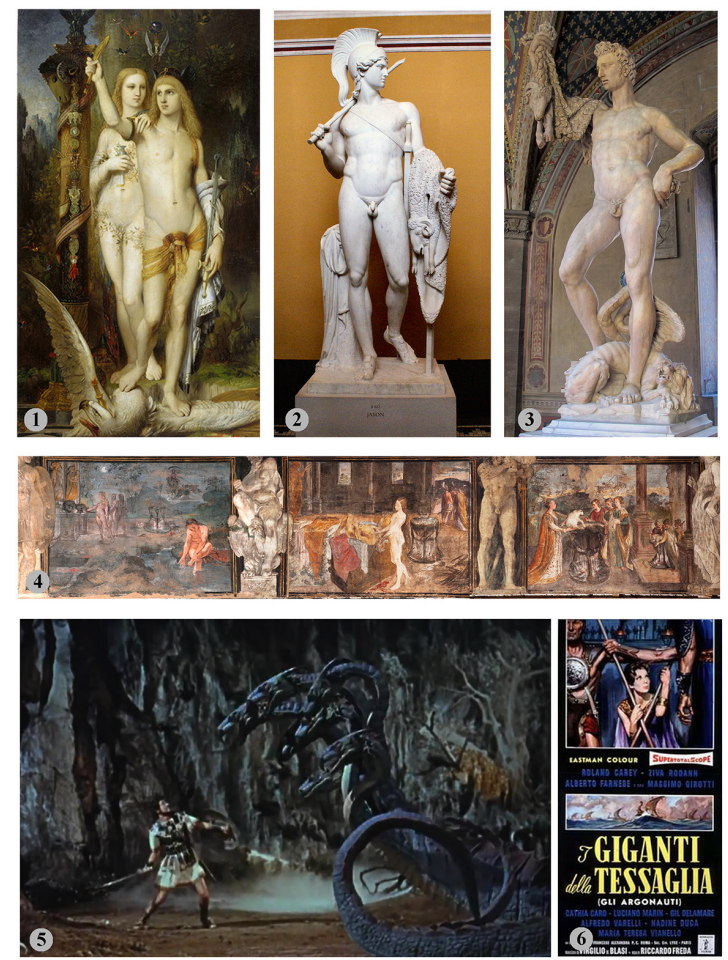
The myth adds the historical story that sees Colchis - a region overlooking the Black Sea and the western part of Caucasian Georgia that has always identified as a certain limit and geographical border between Europe and Asia (fig. 3) - repeatedly losing its original unity following a series of invasions; first by Sciti and Cimmeri in the second half of the seventh century BC, then the scene of arsh wars in the century $\mathrm{VI}$ between the Byzantines and the Persians, who repeatedly tried to open an access to the Black Sea through the region, and ended with the annexation of Darius I to the 19th satrapy of the Persian Empire (5 I5-5 I0 $\mathrm{BC})$.

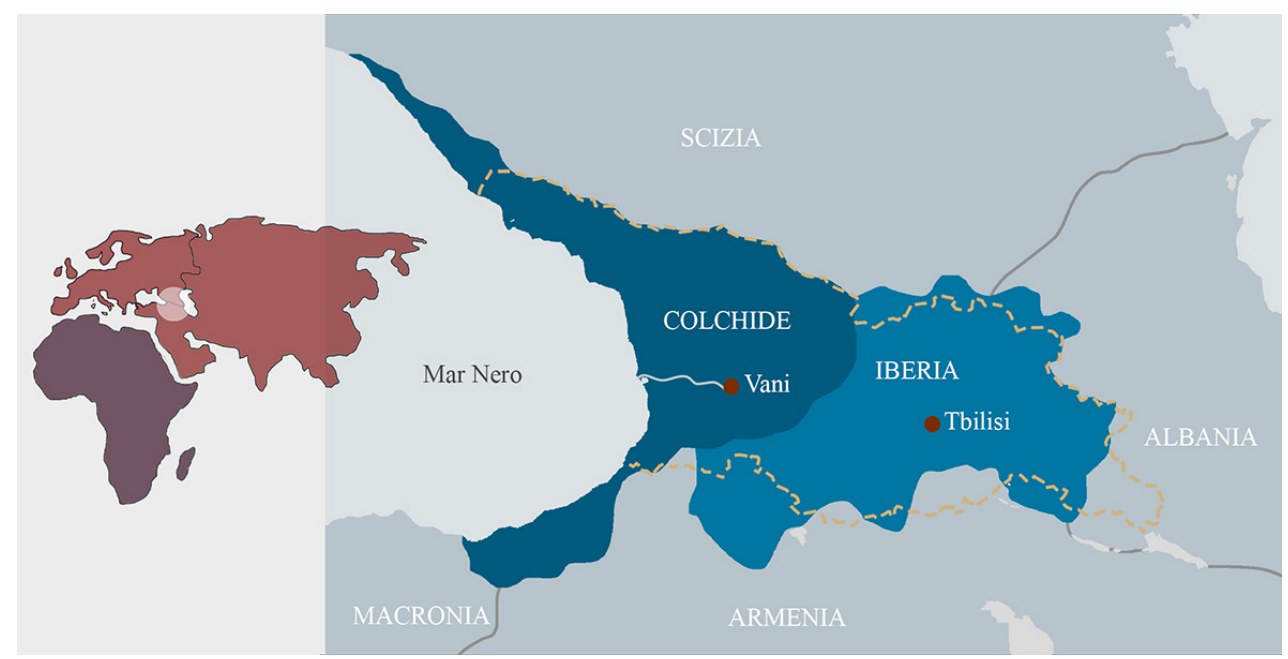

In the orbit of Persia until the conquest of Alexander, Colchis later became part of the Pontic monarchy. At the time of dissolution it was incorporated into the province of Pontus and Bithynia. The region finally came under Roman rule during the third mithridatic war of Gneo Pompeo Magno (65 BC).

The story of the important and rich city of Vani dates back to the 5 centuries ranging from the 8th century BC to destruction in $47 \mathrm{BC}$.

The first phase of the city is dated between the eighth and seventh centuries BC, a period in which Vani was already a significant center of worship. In the 6th century BC the Greeks begin to found some commercial cities on the coasts of the Black Sea, bringing Vani to the center of the main commercial routes that crossed Transcaucasia to reach the port of Phasis, actually named Poti located about $70 \mathrm{~km}$ from Vani (fig. 4).

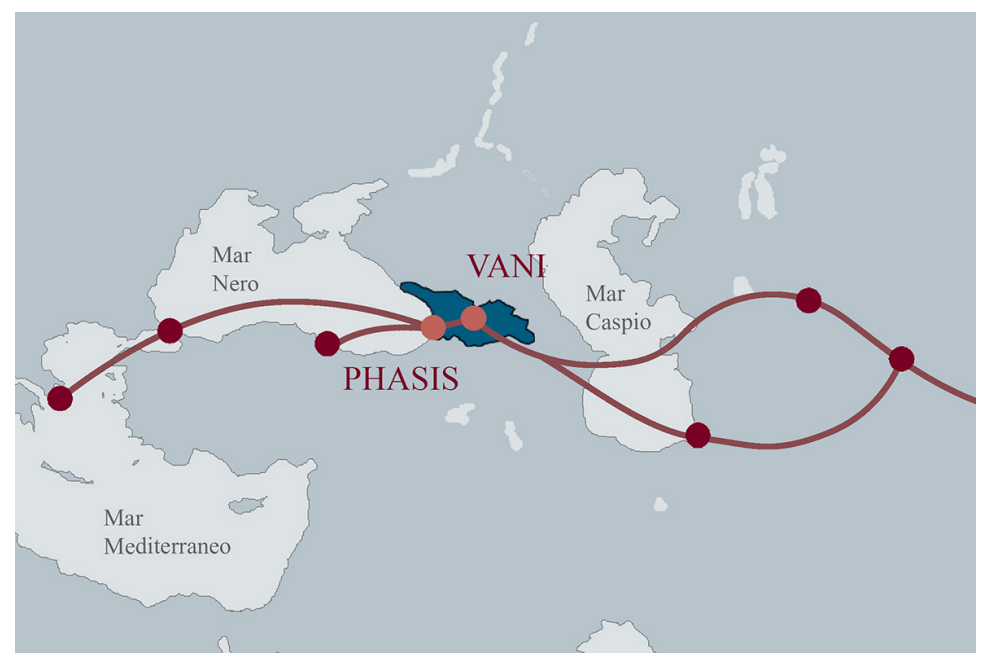


In this phase that will last in time until the third century BCVani undergoes the influence of Greek culture, and the burial places already established since the eighth century are enriched with finely crafted gold, silver and bronze objects. Wooden fortifications are erected around the sanctuary city to signal the importance of the city as political and administrative center of the kingdom [Kacharava, Faudot, Geny 2005].

Starting from 350 BC around and up to the first century BC Vani becomes an important cultic city of the Hellenistic world; in this phase the Round Temple, a series of sacrificial altars and masonry fortifications were built (fig. 5).

The definitive structure of the walls is located around $250 \mathrm{BC}$, a phase to which the two still visible altars and new buildings adorned with bronze sculptures refer.

In 65 BC all Colchis definitively loses its centrality and autonomy and Vani itself sees its importance die out: a first destruction attributed to the king of Pontus Farnace II takes place in $49 \mathrm{BC}$ while in $47 \mathrm{BC}$ the city was definitively destroyed by Mithridates of Pergamum [Treccani online, lemmas: Apollonio Rodio, Argonauti, Colchide].

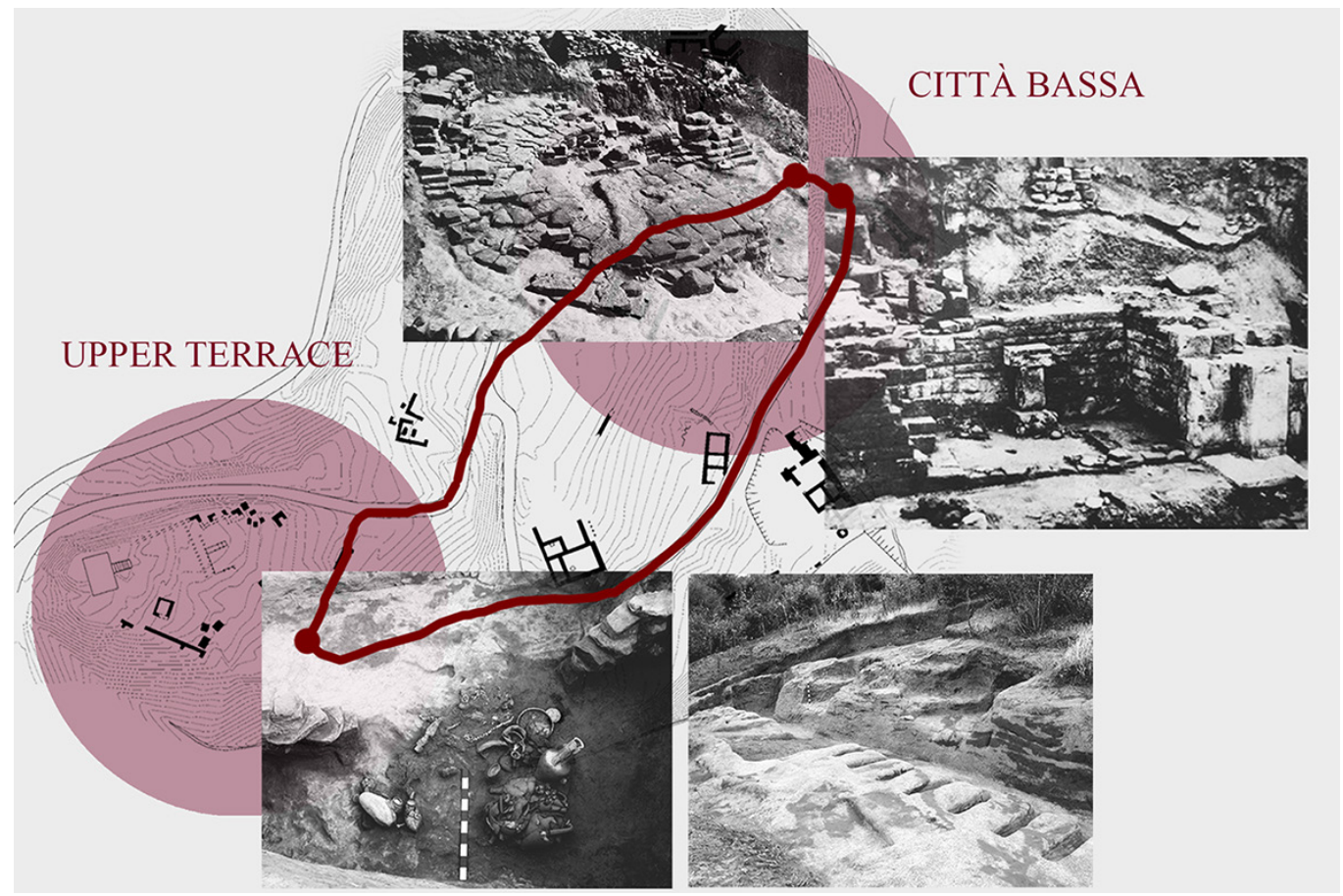

The Vani through Virtual heritage project: documentation and architectural surveys for the enhancement of the archaeological heritage

The research by the historian and archaeologist Takaishvili, who began to study the history of the settlement between the nineteenth and twentieth centuries, preceded the first systematic archaeological campaigns conducted in the Vani area only starting from 1947. The ancient Vani stood on a hill about I 40 meters high on the valley below, a plain furrowed by the Sulori river, a tributary of the Rioni, the ancient Phases at whose mouth Jason and his companions hid the Argo in a shady swamp, they threw anchor and they met to discuss the strategy to be taken to take possession of the golden fleece.

The site, currently studied only for about a third of its extension, has returned a mass of artifacts surprising in number and type: from the VIII-VI century BC phase they came few 
and seriously damaged colchis pottery and clay animals; from the second phase (early 6th-mid 4th century BC) painted pottery of Greek import and new types of food items. But the most significant finding of objects from the rich burial sites is represented by gold jewels, silver and bronze ornaments found in large numbers together with graceful bronze sculptures and luxurious objects indicative of the belonging of the deceased to the elite. Although qualified literature of archaeological documentation presents a state of the art dated and fragmented over time; this does not allow access to up-to-date data or certain attribution of finds to the origin context [Lordkipanidze |99 |; Gamkrelidze 20 I2].

In 2017, the Italian-Georgian project Vani through Virtual heritage [3] was therefore launched and started.

The project has been conceived to build a first documentation of the important archaeological heritage of Vani and to allow a first unitary reconstruction of the context, today impossible due to the fragmented nature of the sources and the dispersion of the location of the mobile remains; the project focuses on architectural survey and representation conceived to know the archaeological context as a complex and multi-scale habitat that embraces the environmental and architectural dimension up to the mobile find [Puma, Nicastro 20 I8].

The work program has been developed thanks to the interdisciplinary team of architects and archaeologists, is carried out by combining teaching and research and is aimed at the metric, morphological and thematic representation of the context through static and dynamic digital graphic outputs based on scientifically validated reconstructions (Principles of Seville, 20I I).

\section{Methodology of the research}

The project workflow integrates traditional procedures aimed at acquiring and representing pairs of information sets relating to the finds and the relative architectural structure of origin [Bertocci, Arrighetti 20I5; Brusaporci 2015]; the procedural synopsis (fig. 6) includes the following work phases, carried out over a period of about 6 months:

A- PHASE I - digital survey

I) preliminary documentation: consisting of research on the case study by selecting and processing existing bibliography, iconography and photographic documentation;

2) campaign plot: the site visit and the visit to the Georgian National Museum in Tbilisi were the first steps of the activities carried out in Georgia to acquire direct knowledge of the archaeological heritage of study; both the visits were managed in order to compare direct informations with the data acquired from the sources and to define the program, the details of the operations to be carried out, the schedule of activities and the tasks;

3) data acquisition from direct and SFM survey of the architectural remains: carried out by measuring and regulating the SFM;

4) data acquisition from SFM survey of the archaeological finds: carried out through a photographic campaign, with metric and color control, of the finds in the Vani Archaeological Museum and in the Georgian National Museum;

5) archiving and cataloging of the data: carried out by organizing the collected data according to a hierarchy managed into 4 levels;

6) post processing: the post processing was carried out by elaborating the data through two photomodeling software according to the scale of the remains, whether structure or find;

7) graphic representations: $2 D$ graphics were made in photorealistic, dotted line and material version on various scales (in 1:20, 1:50, I: 100 scale for the structures and on a I: 2 scale for mobile finds); with the drawings, the 3D models were generated by photomodeling to be subsequently processed also in dynamic visualizations;

B- PHASE II - visual and digital communication: the first finalization of the project consists of the production of two types of visual support represented by a descriptive video of the entire work plan and holograms of mobile finds; 
C- PHASE III - musealisation: the final step of the project concerns the concept of the museum exhibition in Vani, at least by educational services available by devices.

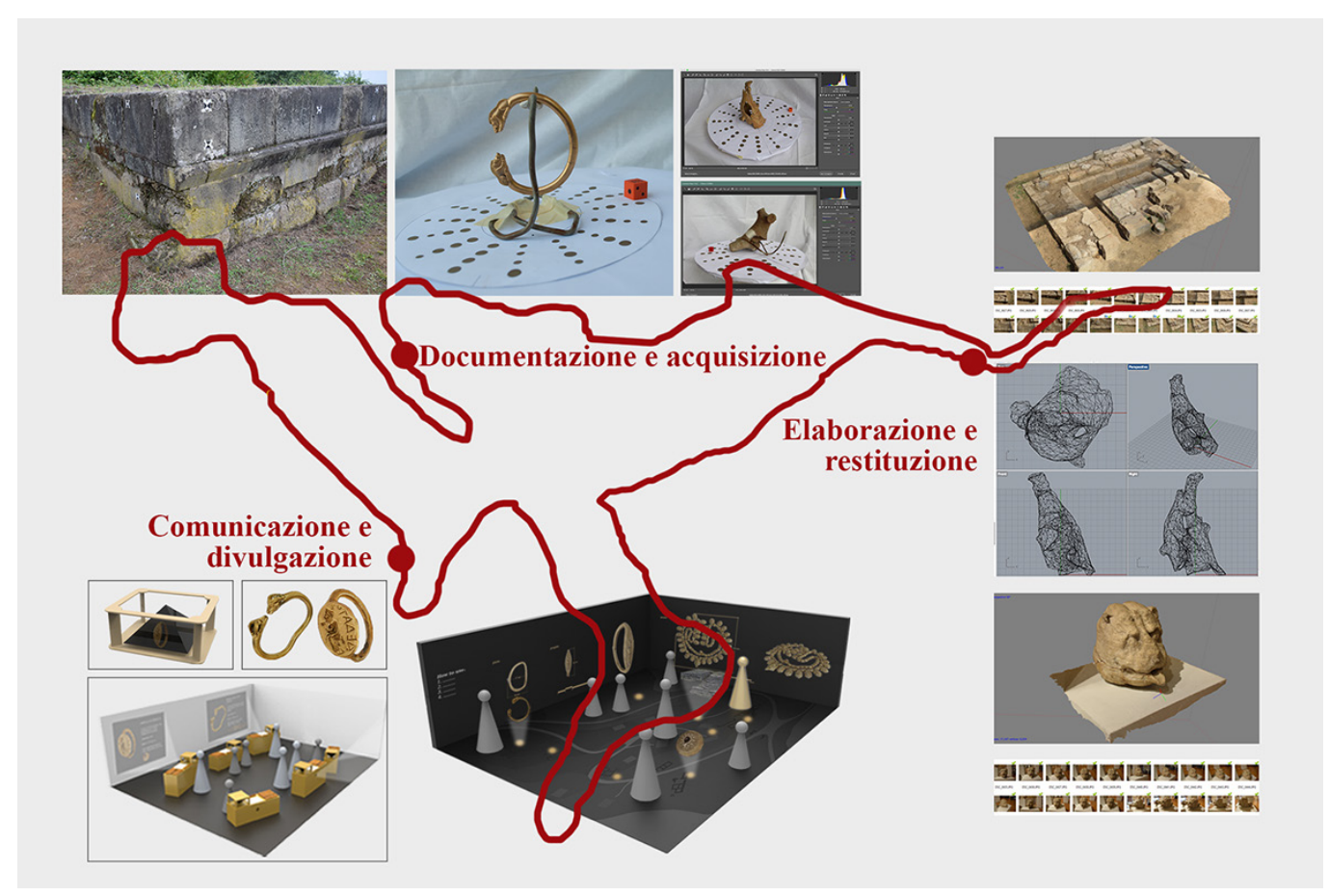

\section{Results and discussion}

As mentioned above, due to the unavailability of the documentation or due to the obliteration of the structure, it was not always possible to reconnect the finds to the origin building but also non reconnectable structures and finds have also been detected for documentary purposes.

In the Upper Terrace, the structures without finds of a ceremonial altar, the 'sanctuary I' and 17 finds from contexts no longer visible today have been detected: from the so-called Tomb of the noble, a bracelet with rams, a bracelet with wild boars, a ring with incision; from the Tomb of the warrior Dédato: the ring and a patera; from Tomb 4, a child's bracelet, in gold with ram-headed ends, (3rd century BC); from the UpperTerrace and dated to the VIII-VII century BC, two figurines of quadrupeds and one of ram, all in terracotta; coming from a context with inaccessible altar located in the defensive complex in the Lower City, an amphora, fragments of a cobblestone pavement, a vase; finally, 4 ceramic furnishings and a bronze statuette of a female figure (fig. 7).

According to the purpose of the project, aimed at reconstructing the contexts unitarily described in virtual heritage through the relocation of the finds in the origin building, from the overall survey campaign two structures were subsequently selected and, at the Vani Archaeological Museum, 3 finds they can be connected to them, including furnishings and architectural fragments.

In particular, the structures with relocable finds have been studied with thematic representations: in the Lower City the defensive complex (together with a zoomorphic chalice) and the ceremonial altar (with a fragment of a bas-relief and an antefix) (fig. 8). 
Fig. 7. Graphic synopsis of some representations, referencing remains and finds.
In addition to these relocatable finds, destined to be fully described in various communication devices, at the Georgian National Museum, the most relevant findings from Vani were studied by SFM survey: the important bronze torso of a young man, dated to the second century BC, a stone capital located in the Round Temple area, two stone lion heads, part of a water drainage system from the Lower City (fig. 9).

Although the civilization of Colchis is an extremely important archaeological area, the most valuable finds from Vani and its region have been moved to the Georgian National Museum of the capital Tbilisi; the archaeological site of Vani is therefore little valued and unknown to most people both for its non-central geographic location and for the lack of easily available information, and cut off from the main tourist routes. The intent of the second axis of the project is connected to this problem and aimed at the preparation of this scientific documentation also in a popular way.
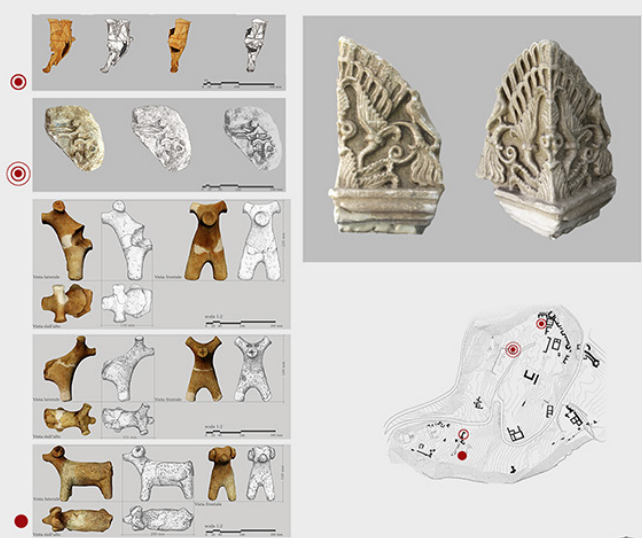<smiles>c1ccc2cc3ccccc3cc2c1</smiles><smiles>[O]</smiles>

से एक्ष<smiles>c1ccccc1</smiles>

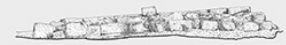
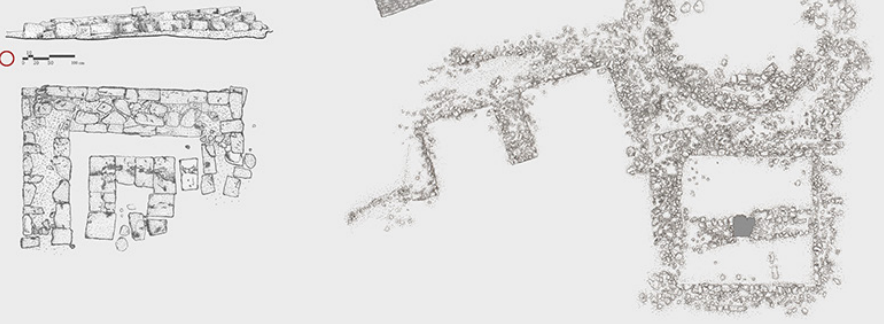
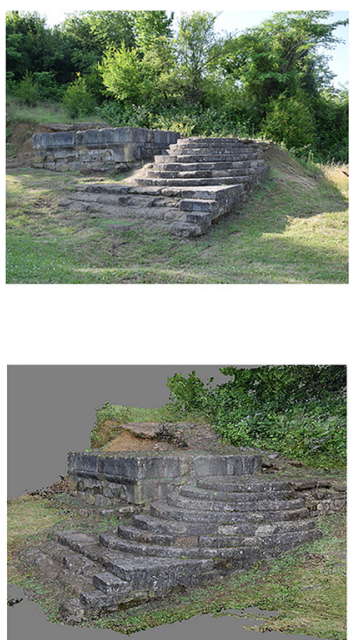

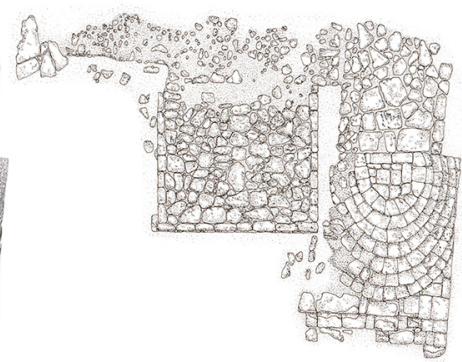

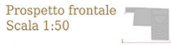
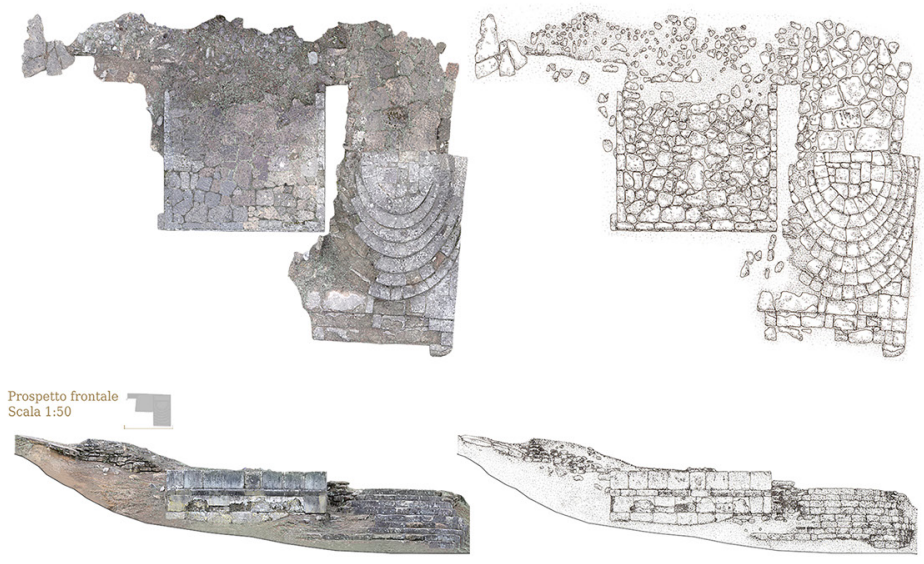<smiles>C1CCCC1</smiles>

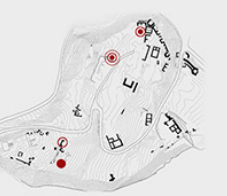

(2)
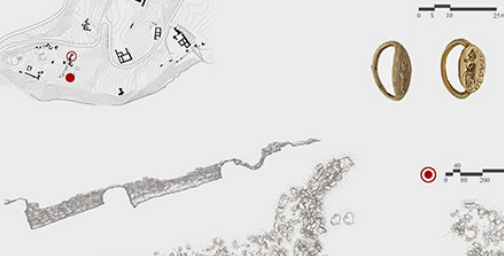

$\circ$<smiles>[C]1[C]=C[C+]=C1</smiles><smiles>[CH]1[CH]C=C1</smiles><smiles>[CH]1[CH]C1</smiles>
cintwitix (a) $\ldots$
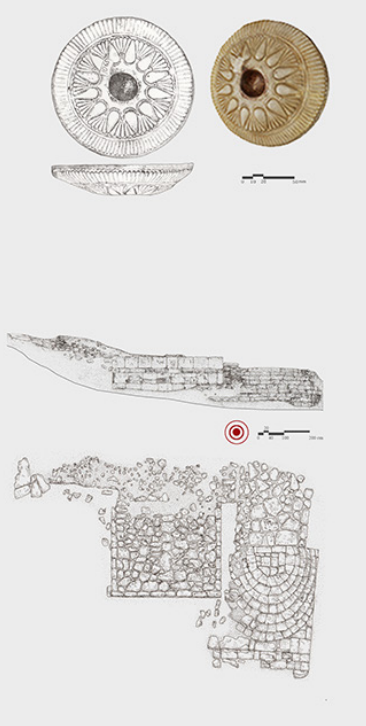
The system conceived for the presentation of the first documentary survey described above is articulated on three axes of action: dissemination of results, museum concept of the finds display, museum concept of the site display. Each axis corresponds to a series of outcomes differentiated by output and communicative choice. The dissemination of the results consists, in fact, of a first step in which a video was created, both as an overview information base and as a necessary reference for subsequent future potential communication steps. Among the many ways of representation and storytelling, the video was chosen for its simplicity of realization, the potential of a multiscale representation, from the overview to the description of particular elements and details, for the versatility of mobile and on site access, the communication flexibility suitable to be calibrated in many edutainment languages. The video organizes and shows the current contents of the site's documentation also to create in the second step a responsive 3D model that provides more and more complex information of unitary reconstruction of the context.

The exhibition of finds is instead conceived in two display solutions: off site and on site, both based on supports for viewing the holograms available in various formats and suitable for different types of mobile devices.

Finally, the arcaheological site museum foresees a design proposal based on overcoming the critical issues, focusing on the main ones: the absence of itineraries to visit the remains, restrictions on access to archaeological areas, absence of information services, low organization of the museum.

Fig. 9. Work phases about finds from Vani: torso of a young man (bronze statue, 2nd century BC), animal figures (stone statues and sime, 2nd Ist century BC).
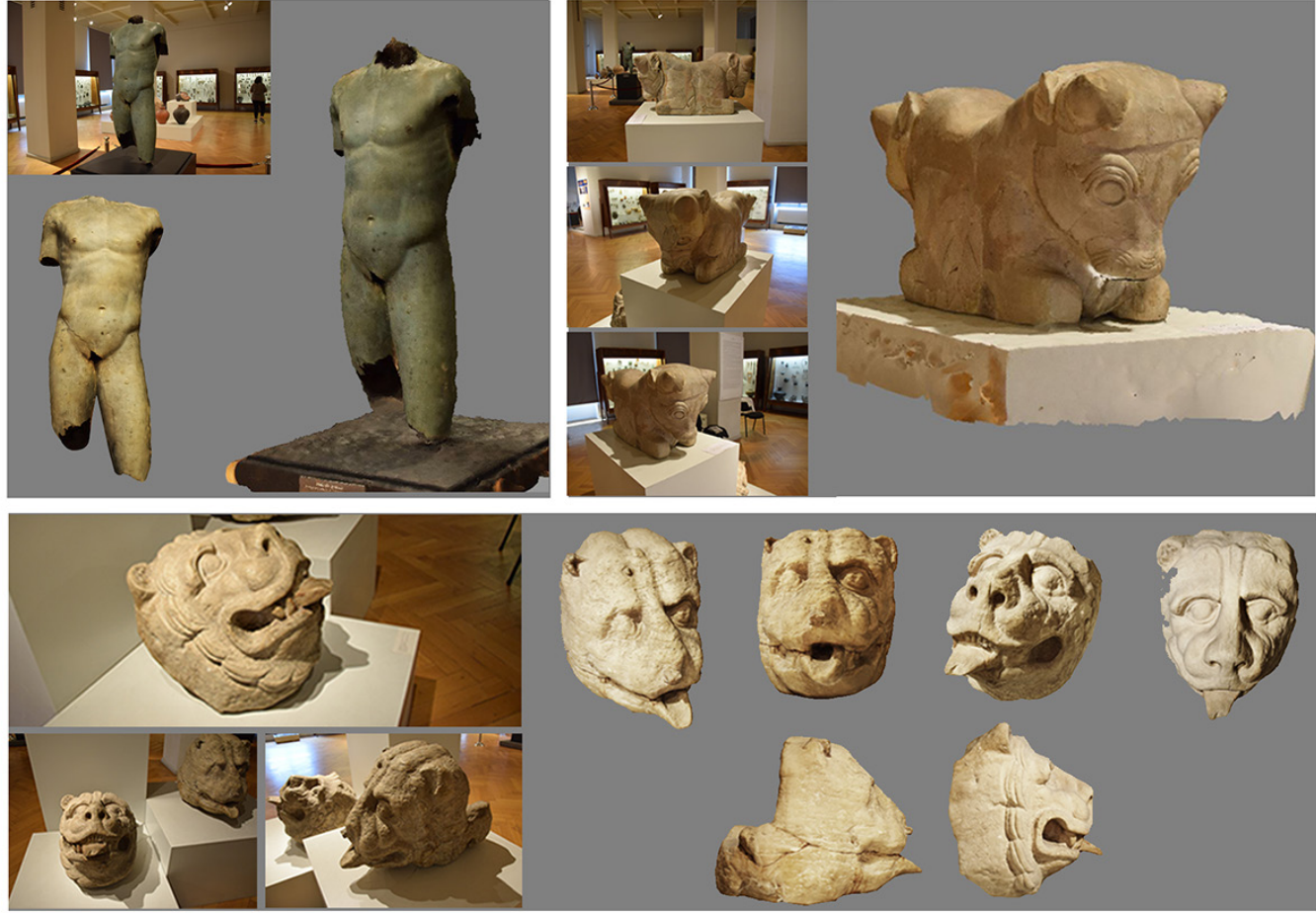

\section{Notes}

[I] In the region that had in Vani a key city of the colco kinodom, the ancient use of sheep skins used as sieves to search for gold in rivers and hung up to dry on trees to extract the golden particles, cannot detache this custom at the birth of the myth of Colchis as of an area literally shining with gold in the su <www.treccani.it/colchide>.

[2] The transmission of the myth over time was expressed first of all by Pindaro's lyric and by the 4 books of the epic poem of the Argonautics by Apollonio Rodio, but later in various other forms: from theatrical to figurative on ceramics, sculpture, painting, TV and cinema films, up to the most recent ludic popularization of board games and video games. 
[3] Vani through Virtual heritage was developed for the mission held in Georgia in 2017 as part of the cultural and scientific collaboration agreement between the University of Florence and the Tbilisi State Academy of Art (responsibles for the agreement, Paola Puma and Nana lashvili). As part of the mission, the joint workshop for the data acquisition "The enhancement of the Georgian archaeological heritage: surveys and representation methodologies" was held in which, together with the teaching activity, has been held the mobility from the University of Florence of one Phd student and three undergraduates, with outcomes developed in three degree theses (Elena Leonardi Vugi, Adele Rossi, Cristina Scicchitano; supervisor prof. Paola Puma, co-supervisor arch. Giuseppe Nicastro, Degree in Architectural Sciences).

\section{References}

Akhvlediani Dimitri, Amaghlobeli Badri, Chi Jennifer, Chichinadze Maia, et al. (2016). The Hoard from the City-Site of Vani. In Bulletin of the Georgian National Academy of Sciences, vol. I0, n. 2, pp. I82-191.

Bertocci Stefano, Arrighetti Andrea (20I5). Survey and documentation for archaeology. In SCIRES-it, 5 (2): <http://caspurciberpublishing.it/index.php/scires-it>.

Blázquez Martinez José María (2005). The sanctuary-city of Vani and its parallels in the west. In Kacharava Daredjan, Faudot Murielle et Geny Evelyne (eds.). Pont-Euxin et polis: polis hellenis et polis barbaron. Actes du Xe Symposium de Vani, $23-26$ septembre 2002: Hommage à Otar Lordkipanidzé et Pierre Lévêque, pp. 235-244. Publications de I'Institut des Sciences et Techniques de l'Antiquité [PUFC 979], Besançon: Presses Universitaires de Franche-Comté.

Brusaporci Stefano (20 I5). Handbook of research on emerging digital tools for architectural surveying, modeling, and representation. Hershey: Igi Global, 2015.

D'Acchille Tiziana (20I I). Alle origini della cultura occidentale. In D'Acchille Tiziana. II Vello d'Oro, antichi tesori della Georgia. Roma: Palombi, pp. 21 - 27 .

Gamkrelidze Gela (20 I2). Researches in Iberia-colchology (History and archaeology of ancient Georgia).Tbilisi: Otar Lordkipanidze centre of archaeology of Georgian National Museum.

Kacharava Daredjan, Faudot Murielle, Geny Evelyne (2005). Pont-Euxin et polis: polis hellenis et polis barbaron. Actes du Xe Symposium de Vani, 23-26 septembre 2002: Hommage à Otar Lordkipanidzé et Pierre Lévêque. Publications de l'Institut des Sciences et Techniques de l'Antiquité [PUFC 979], Besançon: Presses Universitaires de Franche-Comté.

Kacharava Darejan, Kvirkvelia Guram (2009). Recent Archaeological Finds on the Upper Terrace of the Vani Site. In Ancient Civilizations from Scythia to Siberia, nr. 14.

Kacharava Darejan, Kvirkvelia Guram, Chi Jennifer (2008). Wine, Worship, and Sacrifice:The Golden Graves of Ancient Vani. Princeton: Princeton University Press.

Kipiani Guram (20|4). The city of Suriumi.Tbilisi: Artanuji.

Lordkipanidze Otar (199I).Vani: an ancient city of Colchis. Greek. In Roman and Byzantine Studies, 32:2, pp. I 5 I - 195.

Lordkipanidze Otar (1995). Vani une Pompéi géorgienne (Traduzione di Evelyne Geny). Paris: Les Belles Lettres.

Lordkipanidzé Otar (2002). Trade on the Black Sea. An historic forerunner of the Great Silk Road. In Murielle Faudot, Arlette Fraysse et Evelyne Geny (eds.). Pont Euxin et commerce: la genèse de la "route de la soie". Actes du IXe Symposium de Vani (Colchide, 1999). Publications de l'Institut des Sciences et Techniques de l'Antiquité [PUFC 979], Besançon: Presses Universitaires de Franche-Comté, pp. 7-13.

Pescarin Sofia (2016). Digital Heritage into Practice. In SCIRES-it, 6 (I): <http://www.sciresit.it/issue/view/772. Principles of Seville, International principle of Virtual Archaeology, 20 I I. http://smartheritage.com/wp-content/uploads/20I5/03/FINALDRAFT.pdf>

Puma Paola, Nicastro Giuseppe (2018). La documentazione del patrimonio Caucasico: esperienze interdisciplinari in Georgia ed Armenia/The documentation of the Caucasian heritage: interdisciplinary experiences in Georgia and Armenia. In Bertocci Stefano (ed.). Programmi multidisciplinari per l'internazionalizzazione della ricerca. Firenze: Didapress, pp. 22 I-225.

Remondino Fabio, Campana Stefano (2014). 3D Recording and Modeling in Archaeology and Cultural Heritage. Theory and best practices. BAR International Series 2598. Oxford: Archaeopress.

Spagnesi Piero (20 I I). Geografia architettonica dell'antica Colchide fino al primo secolo d.C.. In D'Acchille Tiziana. Il Vello d'Oro, antichi tesori della Georgia. Roma: Palombi, pp. 35-57.

Treccani online, www.treccani.it/: lemmi: Argonauti, Colchide.

\section{Author}

Paola Puma, Università di Firenze, paola.puma@unifi.it

To cite this chapter. Puma Paola (2020). La terra del Vello d'oro tra mito e realtà storica: Vani through Virtual Heritage, il rilievo per la valorizzazione dell'archeologia della Colchide/The Land of the Golden Fleece between Myth and Historical Reality: Vani through Virtual Heritage, the Survey for the Enhancement of Colchis Archaeology. In Arena A., Arena M., Brandolino R.G., Colistra D., Ginex G., Mediati D., Nucifora S., Raffa P. (a cura di). Connettere. Un disegno per annodare e tessere. Atti del $42^{\circ}$ Convegno Internazionale dei Docenti delle Discipline della Rappresentazione/Connecting. Drawing for weaving relationships. Proceedings of the 42th International Conference of Representation Disciplines Teachers. Milano: FrancoAngeli, pp. 2622-2639. 